\title{
$\underline{\mathbf{P}-197}$
}

\section{Pharmacognostical Analysis of the Leaves and Roots of Labisia Pumila (Blume) Fern.-vill. Var. Pumila}

\author{
Jamia Azdina Jamal ${ }^{1, *}$, Ng Kam Siew ${ }^{2}$, Nor Ashila Aladdin², Khairana Husain ${ }^{1}$, Juriyati Jali1 ${ }^{1}$, Hazni \\ Falina Mohamad $^{2}$ and Kartiniwati Muhammad ${ }^{2}$
${ }^{I}$ Drug and Herbal Research Centre, Faculty of Pharmacy, Universiti Kebangsaan Malaysia, Jalan Raja Muda Abdul Aziz, 50300 Kuala Lumpur; ${ }^{2}$ Faculty of Pharmacy, Universiti Kebangsaan Malaysia, Jalan Raja Muda Abdul Aziz, 50300 Kuala Lumpur; E-mail: jamia@pharmacy.ukm.my

Labisia pumila (Blume) Fern.-Vill. (Primulaceae) is locally known as kacip fatimah. There are eight varieties of $L$. pumila, viz.: var. alata, var. discoplacenta, var. malintangensis, var. lanceolata, var. neriifolia, var. gladiata, var. pumila and var. sessilifolia. Based on the WHO methods, a pharmacognostical study was carried out on the leaves and roots of L. pumila (Blume) Fern.-Vill. var. pumila for standardisation of the raw materials. The slightly odoured powdered leaves and roots are dark green and brown, respectively. Microscopical features such as parenchyma cells, rhomboidal calcium oxalate crystals, peltate trichome, starch grains, fibres and spiral vessels were observed in both samples. However, in addition, the leaves had paracytic stomata, polygonal shape of epidermal cell with cicatrices and unicellular covering trichomes, and the roots had cork cells and tracheids. Treatment with concentrated hydrochloric acid gave distinctly different colours, i.e. brown and light yellow, for the leaves and the roots, respectively. Reasonable thin layer chromatographic profiles of the ethanol (96\%) extracts were obtained using silica gel with chloroform-methanol (9:1) and detection with various techniques. Loss on drying values of the roots $(10.00-12.70 \%)$ were higher than the leaves $(9.42-10.40 \%)$. Ethanol-soluble extractives cold and hot methods were obtained for the leaves as $5.71-13.08 \%$ and $8.13-10.52 \%$, and that for the roots as $2.52-12.78 \%$ and $3.90-7.76 \%$, respectively. While cold and hot water-soluble extractives were $10.34-17.90 \%$ and $12.49-14.35 \%$ for the leaves, and $7.82-14.06 \%$ and $12.52-$ $13.66 \%$ for the roots, respectively. In conclusion, the leaves and roots of L. pumila var. pumila had characteristically different pharmacognostic physico-chemical properties.

Keywords: Pharmacognosy, Labisia pumila var. pumila, Primulaceae, standardization. 